\title{
JOURNAL OF EUROPEAN
}

\section{INTEGRATION HISTORY}

\section{REVUE D'HISTOIRE DE}

\section{L'INTÉGRATION EUROPÉENNE}

\section{ZEITSCHRIFT FÜR GESCHICHTE DER}

\section{EUROPÄISCHEN INTEGRATION}

\author{
edited by the
}

Groupe de liaison des professeurs d'histoire contemporaine auprès de la Commission européenne

2008, Volume 14, Number 2



NOMOS Verlagsgessellschaft 


\title{
JOURNAL OF EUROPEAN INTEGRATION HISTORY
}

REVUE D'HISTOIRE DE L'INTÉGRATION EUROPÉENNE

\section{ZEITSCHRIFT FÜR GESCHICHTE DER EUROPÄISCHEN INTEGRATION}

\author{
edited by the \\ Groupe de liaison des professeurs d'histoire contemporaine \\ auprès de la Commission européenne
}

2008, Volume 14, Number 2 
The Liaison Committee of Historians came into being in 1982 as a result of an important international symposium that the Commission had organized in Luxembourg to launch historical research on European integration. The committee is composed of historians of the European Union member countries who work on contemporary history.

The Liaison Committee:

- gathers and conveys information about work on European history after the Second World War;

- advises the European Union on research projects concerning contemporary European history. Thus, the Liaison Committee was commissioned to make publicly available the archives of the Community institutions;

- enables researchers to make better use of the archival sources;

- promotes research meetings to get an update of work in progress and to stimulate new research: seven research conferences have been organized and their proceedings published.

The Journal of European Integration History - Revue d'histoire de l'intégration européenne - Zeitschrift für Geschichte der europäischen Integration is in line with the preoccupations of the Liaison Committee. Being the first history journal to deal exclusively with the history of European Integration, the Journal offers the increasing number of young historians devoting their research to contemporary Europe, a permanent forum.

The Liaison Committee works completely independently and according to historians' critical method.

*

Le Groupe de liaison des professeurs d'histoire contemporaine auprès de la Commission des Communautés européennes s'est constitué en 1982 à la suite d'un grand colloque que la Commission avait organisé à Luxembourg pour lancer la recherche historique sur la construction européenne. Il regroupe des professeurs d'université des pays membres de l'Union européenne, spécialistes d'histoire contemporaine.

Le Groupe de liaison a pour mission:

- de diffuser l'information sur les travaux portant sur l'histoire de l'Europe après la Seconde Guerre mondiale;

- de conseiller l'Union européenne sur les actions scientifiques à entreprendre avec son appui; ainsi le Groupe de liaison a assuré une mission concernant la mise à la disposition du public des archives des institutions communautaires;

- d'aider à une meilleure utilisation par les chercheurs des moyens de recherche mis à leur disposition (archives, sources orales...);

- d'encourager des rencontres scientifiques afin de faire le point sur les connaissances acquises et de susciter de nouvelles recherches: sept grands colloques ont été organisés et leurs actes publiés. L'édition du Journal of European Integration History - Revue d'histoire de l'intégration européenne - Zeitschrift für Geschichte der europäischen Integration se situe dans le droit fil des préoccupations du Groupe de liaison. Première revue d'histoire à se consacrer exclusivement à l'histoire de la construction européenne, le Journal se propose de fournir un forum permanent au nombre croissant de jeunes historiens vouant leurs recherches à l'Europe contemporaine.

Le Groupe de liaison organise ses colloques et publications en toute indépendance et conformément à la méthode critique qui est celle des historiens. 


\title{
JOURNAL OF EUROPEAN INTEGRATION HISTORY
}

\author{
REVUE D'HISTOIRE DE L'INTÉGRATION EUROPÉENNE
}

\section{ZEITSCHRIFT FÜR GESCHICHTE DER EUROPÄISCHEN INTEGRATION}

\author{
2008, Volume 14, Number 2 \\ N. Piers Ludlow, coordinator
}

\section{N. Piers LUDLOW}

Introduction

Anne BOERGER-DE SMEDT

La Cour de Justice dans les négociations du traité de Paris

instituant la CECA

Jérôme WILSON

Jurisconsultes et conseillers d'État: aux origines de l'ordre juridique

communautaire

Bill DAVIES

Meek Acceptance? The West German Ministeries' Reaction to the

Van Gend en Loos and Costa decisions

Morten RASMUSSEN

The Origins of a Legal Revolution - The Early History of the

European Court of Justice.

Giles SCOTT-SMITH

An Outpost of Atlanticism: Leonard Tennyson, the European Delegation in

Washington and the Transformation of US-European Relations 1954-1974

Andrea BECHERUCCI

Lionello Levi Sandri au service de l'Europe

Dagmar MORAVCOVÁ

Vom Traum zur Realität: Der Perzeptionswandel „Europa“ während der

Transformation der ČSFR/ČR, 1989-2004

Book reviews - Comptes rendus - Buchbesprechungen

Abstracts - Résumés - Zusammenfassungen

Notices - Informations - Mitteilungen

Contributors - Auteurs - Autoren

Books received - Livres reçus - Eingegangene Bücher 


\section{Editorial notice}

Articles for inclusion in this journal may be submitted at any time. The editorial board will then arrange for the article to be refereed. Articles should not be longer than 6000 words, footnotes included. They may be in English, French or German.

Articles submitted to the Journal should be original contributions and not be submitted to any other publication at the same time as to the Journal of European Integration History. Authors should retain a copy of their article. The publisher and editors cannot accept responsibility for loss of or damage to authors' typescripts or disks.

The accuracy of, and views expressed in articles and reviews are the sole responsibility of the authors.

Authors should ensure that typescripts conform with the journal style. Prospective contributors should obtain further guidelines from the Editorial Secretariat.

Articles, reviews, communications relating to articles and books for review should be sent to the Editorial Secretariat.

\section{Citation}

The Journal of European Integration History may be cited as follows:

JEIH, (Year)/(Number), (Page).

\section{ISSN 0947-9511}

(C) 2008 NOMOS Verlagsgesellschaft, Baden-Baden and the Groupe de liaison des professeurs d'histoire contemporaine auprès de la Commission européenne. Printed in Germany.

All rights reserved. No part of this publication may be reproduced, stored in a retrieval system, or transmitted in any form or by any means, mechanical, photocopying, recording or otherwise, without prior permission of the publishers. 